\title{
High-level Gentamicin Resistance among Clinical Isolates of Enterococci in Iran: a Systematic Review and Meta-analysis
}

\author{
Milad Shahini Shams Abadi ${ }^{1}$, Asieh Taji ${ }^{2}$, Fatemeh Salehi ${ }^{3}$, Hossein Kazemian ${ }^{4}$, Hamid Heidari ${ }^{5}$ \\ ${ }^{1}$ Department of Microbiology and Immunology, Cellular and Molecular Research Center, Basic Health Sciences Institute, Shahrekord University of Medical \\ Sciences, Shahrekord, Iran \\ ${ }^{2}$ Department of Bacteriology and Virology, School of Medicine, Shiraz University of Medical Sciences, Shiraz, Iran \\ ${ }^{3}$ Modeling in Health Research Center, Shahrekord University of Medical Sciences, Shahrekord, Iran \\ ${ }^{4}$ Department of Microbiology, Faculty of Medicine, Ilam University of Medical Sciences, Ilam, Iran \\ ${ }^{5}$ Department of Microbiology, Faculty of Medicine, Shahid Sadoughi University of Medical Sciences, Yazd, Iran
}

Corresponding author: Hamid Heidari, Department of Microbiology, Faculty of Medicine, Shahid Sadoughi University of Medical Sciences, Yazd, Iran; E-mail: heidarii.hamid@gmail.com; Tel.: +98-9386312941

Received: 22 Apr 2020 Accepted: 1 June 2020 Published: 28 Feb 2021

Citation: Abadi MSS, Taji A, Salehi F, Kazemian H, Heidari H. High-level gentamicin resistance among clinical isolates of enterococci in Iran: A systematic review and meta-analysis. Folia Med (Plovdiv) 2021;63(1):15-23. doi: 10.3897/folmed.63.e53506.

\begin{abstract}
Enterococci have been considered as one of the most common causes of nosocomial infections. The spread of antibiotic resistance has posed a serious challenge to treating the enterococcal infections. High-level aminoglycosides resistance leads to failure in the synergistic combination therapy.

This study aimed to estimate the prevalence of high-level gentamicin resistance (HLGR) among clinical isolates of enterococci in Iran.

Systematic literature search was conducted in the Web of Science, PubMed, Scopus and Google Scholar electronic databases from articles which were published from April 2000 to September 2018. Literature search yielded 918 studies. Eligible studies were selected according to the defined inclusion and exclusion criteria. Statistical heterogeneity was estimated by $\mathrm{Q}$ statistic and the $\mathrm{I}^{2}$ index. The Begg's rank correlation test and Egger's weighted regression tests were used to evaluate possible publication bias.
\end{abstract}

Nineteen studies were included in this review. According to the meta-analysis results, the prevalence of HLGR among Enterococcus spp. was $49.4 \%$ (95\% CI: $42.2 \%-56.6 \%$ ). It was estimated $44.3 \%$ (95\% CI: $38.1 \%-50.8 \%$ ) and 66.3\% (95\% CI: 51.4\%-78.6\%) for E. faecalis and E. faecium, respectively.

Since notable rate of HLGR in enterococci was seen in this analysis, improving the implementation of all aspects of the infection control programmes is required. Accurate and regular monitoring of infection control procedures are necessary for reducing the dissemination of such infections.

\section{Keywords}

Enterococcus, Iran, high-level gentamicin resistance (HLGR), meta-analysis, systematic review 


\section{INTRODUCTION}

Enterococci are common inhabitants of the human gastrointestinal tract and they are known to be potent pathogens responsible for several infections in humans. ${ }^{1}$ Enterococci have been considered as one of the most common causes of nosocomial infections worldwide. ${ }^{2}$ The spread of antibiotic resistance has posed a serious challenge to the treatment of the enterococcal infections. ${ }^{3}$ Simultaneous prescription of aminoglycosides and cell wall active agents (such as $\beta$-lactams or vancomycin) will be synergistically effective against severe infections. ${ }^{4}$ In 1979, high-level aminoglycosides resistance in enterococci was initially described in the US. ${ }^{5}$ High-level resistance (HLR) to the aminoglycosides leads to failure in the synergistic combination therapy. ${ }^{4,6}$ Moreover, horizontal HLR associated genes transfer is common between various strains and it can increase the risk of the development and dissemination of such resistance in enterococci. ${ }^{7}$

According to available data, the prevalence rates of high-level gentamicin resistance (HLGR) in enterococci have been reported from several parts of Iran. ${ }^{1,8-11}$ However, there is no comprehensive analysis regarding HLGR amongst Enterococcus isolates, obtained from several infections in the country. Therefore, the aim of the present study was to assess the prevalence of HLGR among clinical isolates of enterococci in Iran using a systematic review and meta-analysis conforms to the Preferred Reporting Items for Systematic Reviews and Meta-Analyses.

\section{MATERIALS AND METHODS}

\section{Search strategies}

A systematic literature search was conducted in the Web of Science, PubMed, Scopus, and Google Scholar electronic databases from papers that were published from April 2000 to September 2018 following the PRISMA (the Preferred Reporting Items for Systematic Reviews and Meta-Analyses) guidelines. The following keywords, "Enterococcus" or "E. faecalis" or E. faecium and "high level aminoglycoside resistant" or "high level gentamicin resistant" or "HLGR" in combination with "Iran" were searched as scientific terms in the present survey. We also searched bibliographies of retrieved articles for additional references.

\section{Eligibility criteria and study selection}

Cross-sectional or cohort studies that reported the prevalence of HLGR in Iran were considered. To determine the articles which had inclusion criteria, the titles, abstracts and full texts were screened independently by two reviewers and any discrepancies were resolved by consensus. The articles published in English or Persian language which were indexed in PubMed or Scopus with the follo- wing characteristics were included: standard used methods for HLGR detection in Enterococcus strains and reported data on number of HLGR among Enterococcus strains. According to the Clinical and Laboratory Standards Institute (CLSI) guidelines ${ }^{12}$, standard methods for detecting HLGR among Enterococcus strains are broth dilution, agar dilution, and disk diffusion methods by high-content gentamicin $(120 \mu \mathrm{g})$. Additionally, research that has been conducted by non-Iranian authors on the Iranian population or samples were also assessed. Studies with nonstandard methods and without report of HLGR prevalence were excluded. We also excluded studies which their sample size was less than 10 isolates, nonhuman studies, review articles, meta-analyses or systematic reviews, congress abstracts and duplicate publication of the same studies.

\section{Data extraction and definitions}

Data collection was performed in parallel by two authors and discrepancies were resolved by a third author. Data collected included: first author's name, the study performing time, publication date, the study setting, sample size (number of Enterococcus, E. faecalis and E. faecium isolates) and prevalence of HLGR.

\section{Statistical analysis}

Analysis of data was performed by Comprehensive Meta-Analysis Software v. 2.2 (Bio stat Company). Meta-analysis was performed using random effects model to estimate pooled prevalence and corresponding 95\% confidence interval (CI). Statistical heterogeneity between and within groups was estimated by the $\mathrm{Q}$ statistic and the $\mathrm{I}^{2}$ index. The Begg's rank correlation test and Egger's weighted regression tests were used to evaluate possible publication bias $(p<0.05$ was considered indicative of a statistically significant publication bias).

\section{RESULTS}

The literature search yielded 918 studies, 856 were excluded based on their index and review of title and abstract, leaving 62 articles for full text review. Of 62 reviewed studies, HLGR was not detected in 22 studies according to the standard methods, 12 studies did not report the prevalence of Enterococcus or Enterococcus spp., 4 studies had sample size less than 10 isolates, and the results of 5 studies were unclear. Eventually, 19 eligible studies were chosen for final analysis. There were no overlapping study populations in the final review. Fig. 1 shows the study selection process and reasons for exclusion. None of the included studies received direct funding from pharmaceutical companies. The full results of included articles, the prevalence of $E$. faecalis and E. faecium and the frequency of HLGR amongst them are presented in Table $\mathbf{1}$. 


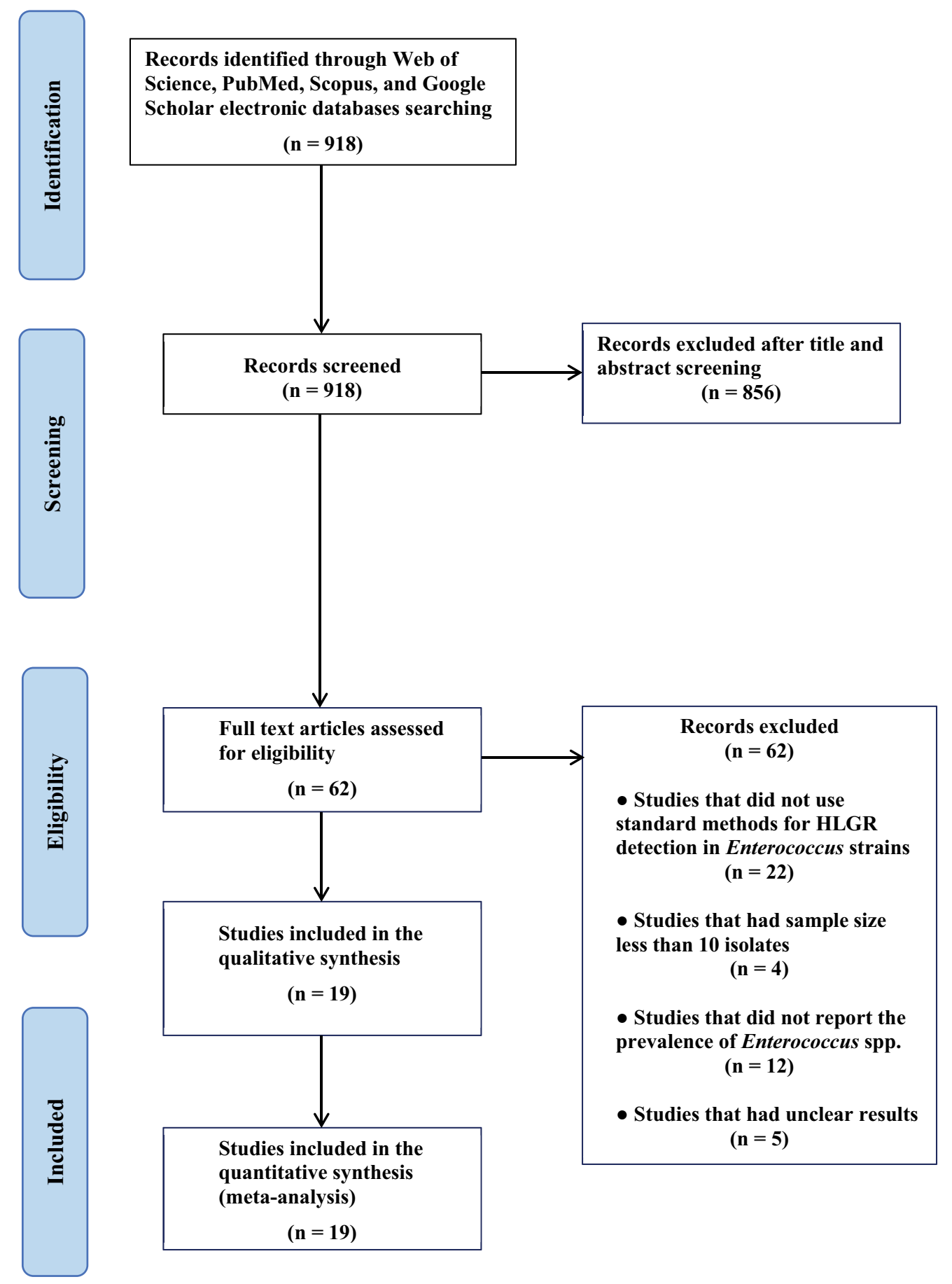

Figure 1. Summary of the literature search and study selection. HLGR: high-level gentamicin resistance.

Nineteen studies investigated the frequency of HLGR among Enterococcus spp. The pooled prevalence for HLGR among Enterococcus isolates was 49.4\% (95\% CI: 42.2\%$56.6 \%$ ) ranging from $15 \%$ to $96 \%$ (Fig. 2). There was a significant heterogeneity among the 19 studies $\left(\chi^{2}=301.393\right.$; $\left.p<0.001 ; \mathrm{I}^{2}=94 \%\right)$. Additionally, Begg's and Egger's tests were performed to quantitatively evaluate the publication biases. The results of Begg's test $(\mathrm{z}=0.42, p=0.67)$ and Egger's test $(\mathrm{t}=0.54, p=0.6)$ showed no evidence of publication bias.
According to the included publications, in 15 studies the frequency of HLGR in E. faecalis strains was investigated. The pooled prevalence of HLGR among E. faecalis isolates was $44.3 \%$ (95\% CI: $38.1 \%-50.8 \%$ ) ranging from $24 \%$ to $65 \%$ (Fig. 3). There was a significant heterogeneity among the 15 studies $\left(\chi^{2}=111.703 ; p<0.001 ; \mathrm{I}^{2}=87.47 \%\right)$. There was no evidence of publication bias according to Begg's rank correlation analysis $(\mathrm{z}=0.1, p=0.92)$. Egger's regression analysis also confirmed there is no evidence of publication bias $(\mathrm{t}=1.08, p=0.3)$. 
Table 1. Characteristics of studies included in the meta-analysis

\begin{tabular}{|c|c|c|c|c|c|c|c|c|c|c|}
\hline \multicolumn{5}{|c|}{ Study Details } & \multicolumn{3}{|c|}{ Size (n) } & \multicolumn{3}{|c|}{ HLGR } \\
\hline Author & $\begin{array}{l}\text { Publica- } \\
\text { tion year }\end{array}$ & $\begin{array}{l}\text { Years of } \\
\text { study }\end{array}$ & $\begin{array}{l}\text { City or } \\
\text { Region }\end{array}$ & Diagnostic method & $\begin{array}{l}\text { Sample } \\
\text { size }\end{array}$ & $\begin{array}{l}\text { E. fae- } \\
\text { calis }\end{array}$ & $\begin{array}{l}\text { E.fae- } \\
\text { cium }\end{array}$ & Total & $\begin{array}{l}\text { E. fae- } \\
\text { calis }\end{array}$ & $\begin{array}{l}\text { E. fae- } \\
\text { cium }\end{array}$ \\
\hline Feizabadi et al. ${ }^{13}$ & 2003 & $\begin{array}{l}2000- \\
2001\end{array}$ & Tehran & $\begin{array}{l}\text { Broth microdilution } \\
\text { method }\end{array}$ & 59 & 59 & - & 18 & 18 & - \\
\hline Feizabadi et al. ${ }^{14}$ & 2004 & $\begin{array}{l}2000- \\
2002\end{array}$ & Tehran & $\begin{array}{l}\text { Macro-broth dilution } \\
\text { method }\end{array}$ & 182 & 182 & - & 76 & 76 & - \\
\hline Feizabadi et al. ${ }^{15}$ & 2006 & $\begin{array}{l}2002- \\
2004\end{array}$ & Tehran & $\begin{array}{l}\text { Broth microdilution } \\
\text { method }\end{array}$ & 114 & 79 & 35 & 59 & 42 & 17 \\
\hline Saifi et al. ${ }^{16}$ & 2008 & $\begin{array}{l}2005- \\
2006\end{array}$ & Tehran & $\begin{array}{l}\text { Broth microdilution } \\
\text { method }\end{array}$ & 638 & 496 & 142 & 295 & 158 & 137 \\
\hline Emaneini et al. ${ }^{17}$ & 2008 & UN & Tehran & Agar dilution method & 326 & 210 & 116 & 171 & 106 & 65 \\
\hline $\begin{array}{l}\text { Soltan Dallal et } \\
\text { al. }{ }^{18}\end{array}$ & 2008 & $\begin{array}{l}2005- \\
2006\end{array}$ & Tehran & $\begin{array}{l}\text { DDM by high-content } \\
\text { gentamicin }(120 \mu \mathrm{g})\end{array}$ & 147 & 104 & 43 & 98 & 64 & 34 \\
\hline Feizabadi et al. ${ }^{19}$ & 2008 & $\begin{array}{l}2006- \\
2007\end{array}$ & Tehran & $\begin{array}{l}\text { DDM by high-content } \\
\text { gentamicin }(120 \mu \mathrm{g})\end{array}$ & 102 & 102 & - & 66 & 66 & - \\
\hline Aligholi et al..$^{20}$ & 2009 & UN & Tehran & $\begin{array}{l}\text { Broth microdilution } \\
\text { method }\end{array}$ & 495 & 320 & 157 & 233 & 134 & 93 \\
\hline Saifi et al. ${ }^{21}$ & 2009 & $\begin{array}{l}2005- \\
2006\end{array}$ & Tehran & $\begin{array}{l}\text { Broth microdilution } \\
\text { method }\end{array}$ & 320 & - & 75 & 48 & - & - \\
\hline Jabalameli et al. ${ }^{22}$ & 2009 & $\begin{array}{l}2002- \\
2004\end{array}$ & Tehran & Agar dilution method & 413 & 277 & 123 & 215 & - & - \\
\hline Hasani et al. ${ }^{23}$ & 2012 & $\begin{array}{l}2008- \\
2010\end{array}$ & $\begin{array}{l}\text { Northwest } \\
\text { Iran }\end{array}$ & Agar dilution method & 220 & 152 & 68 & 136 & 79 & 54 \\
\hline Dadfarma et al. ${ }^{8}$ & 2013 & 2009 & Tehran & $\begin{array}{l}\text { Broth microdilution } \\
\text { method }\end{array}$ & 142 & 90 & 47 & 62 & 38 & 21 \\
\hline Behnood et al. ${ }^{10}$ & 2013 & $\begin{array}{l}2009- \\
2011\end{array}$ & $\begin{array}{l}\text { Northwest } \\
\text { Iran }\end{array}$ & Agar dilution method & 111 & 89 & 22 & 36 & 23 & 13 \\
\hline Emaneini et al. ${ }^{24}$ & 2016 & 2012 & Tehran & $\begin{array}{l}\text { DDM by high-content } \\
\text { gentamicin }(120 \mu \mathrm{g})\end{array}$ & 27 & 19 & 8 & 26 & - & - \\
\hline Khani et al. ${ }^{25}$ & 2016 & $\begin{array}{l}2011- \\
2012\end{array}$ & Kermanshah & $\begin{array}{l}\text { Broth microdilution } \\
\text { method }\end{array}$ & 138 & 63 & 33 & 123 & - & - \\
\hline $\begin{array}{l}\text { Esmailzadeh et } \\
\text { al. }{ }^{26}\end{array}$ & 2016 & $\begin{array}{l}2013- \\
2014\end{array}$ & Kashan & $\begin{array}{l}\text { Broth microdilution } \\
\text { method }\end{array}$ & 180 & 108 & 72 & 43 & 26 & 17 \\
\hline Heidari et al. ${ }^{1}$ & 2016 & $\begin{array}{l}2013- \\
2014\end{array}$ & Tehran & $\begin{array}{l}\text { Broth microdilution } \\
\text { method }\end{array}$ & 57 & 46 & 2 & 31 & 30 & 1 \\
\hline Heidari et al. ${ }^{9}$ & 2017 & $\begin{array}{l}2015- \\
2016\end{array}$ & Shiraz & $\begin{array}{l}\text { DDM by high-content } \\
\text { gentamicin }(120 \mu \mathrm{g})\end{array}$ & 51 & 51 & - & 27 & 27 & - \\
\hline Amini et al. ${ }^{11}$ & 2018 & 2016 & Kermanshah & $\begin{array}{l}\text { DDM by high-content } \\
\text { gentamicin }(120 \mu \mathrm{g})\end{array}$ & 108 & 94 & 14 & 46 & 33 & 13 \\
\hline
\end{tabular}

DDM: disk diffusion method

We found 10 articles which investigated the frequency of HLGR in E. faecium isolates (one study was excluded because the sample size for E. faecium was less than ten). The pooled prevalence of HLGR in E. faecium isolates was $66.3 \%$ (95\% CI: $51.4 \%-78.6 \%$ ) ranging from $24 \%$ to $96 \%$ (Fig. 4). Based on Q statistic and the $\mathrm{I}^{2}$ index, heterogeneity was significant $\left(\chi^{2}=100.387 ; p<0.001 ; \mathrm{I}^{2}=91 \%\right)$. Also, the Begg's rank correlation analysis $(\mathrm{z}=1.25, p=0.21)$ and
Egger's regression analysis $(\mathrm{t}=1.2, p=0.26)$ confirmed no evidence of publication bias.

\section{DISCUSSION}

To the best of our knowledge, this study is the first systematic review regarding the prevalence of HLGR amongst 


\section{Study name}

$\begin{array}{lccccc} & \text { Total } & \begin{array}{c}\text { Relative } \\ \text { weight }\end{array} & \begin{array}{c}\text { Event } \\ \text { rate }\end{array} & \begin{array}{c}\text { Lower } \\ \text { limit }\end{array} & \begin{array}{c}\text { Upper } \\ \text { limit }\end{array} \\ \text { Feizabadi 2003 } & 18 / 59 & 4.92 & 0.305 & 0.201 & 0.433 \\ \text { Feizabadi 2004 } & 76 / 182 & 5.64 & 0.418 & 0.348 & 0.490 \\ \text { Feizabadi 2006 } & 59 / 114 & 5.47 & 0.518 & 0.426 & 0.608 \\ \text { Saifi 2008 } & 295 / 638 & 5.89 & 0.462 & 0.424 & 0.501 \\ \text { Emaneini 2008 } & 171 / 326 & 5.80 & 0.525 & 0.470 & 0.578 \\ \text { Soltan Dallal 2008 98/147 } & 5.53 & 0.667 & 0.587 & 0.738 \\ \text { Feizabadi 2008 } & 66 / 102 & 5.36 & 0.647 & 0.550 & 0.733 \\ \text { Aligholi 2009 } & 233 / 495 & 5.86 & 0.471 & 0.427 & 0.515 \\ \text { Saifi 2009 } & 48 / 320 & 5.62 & 0.150 & 0.115 & 0.193 \\ \text { Jabalameli 2009 } & 215 / 413 & 5.84 & 0.521 & 0.472 & 0.568 \\ \text { Hasani 2012 } & 136 / 220 & 5.69 & 0.618 & 0.552 & 0.680 \\ \text { Dadfarma 2013 } & 62 / 142 & 5.56 & 0.437 & 0.357 & 0.519 \\ \text { Behnood 2013 } & 36 / 111 & 5.39 & 0.324 & 0.244 & 0.417 \\ \text { Emaneini 2016 } & 26 / 27 & 1.56 & 0.963 & 0.779 & 0.995 \\ \text { Khani 2016 } & 123 / 138 & 4.97 & 0.891 & 0.828 & 0.933 \\ \text { Esmailzadeh 201643/180 } & 5.53 & 0.239 & 0.182 & 0.307 \\ \text { Heidari 2016 } & 31 / 57 & 5.02 & 0.544 & 0.415 & 0.668 \\ \text { Heidari 2017 } & 27 / 51 & 4.93 & 0.529 & 0.394 & 0.661 \\ \text { Amini 2018 } & 46 / 108 & 5.43 & 0.426 & 0.336 & 0.521 \\ & & & 0.494 & 0.422 & 0.566\end{array}$

\section{Event rate and $95 \% \mathrm{Cl}$}

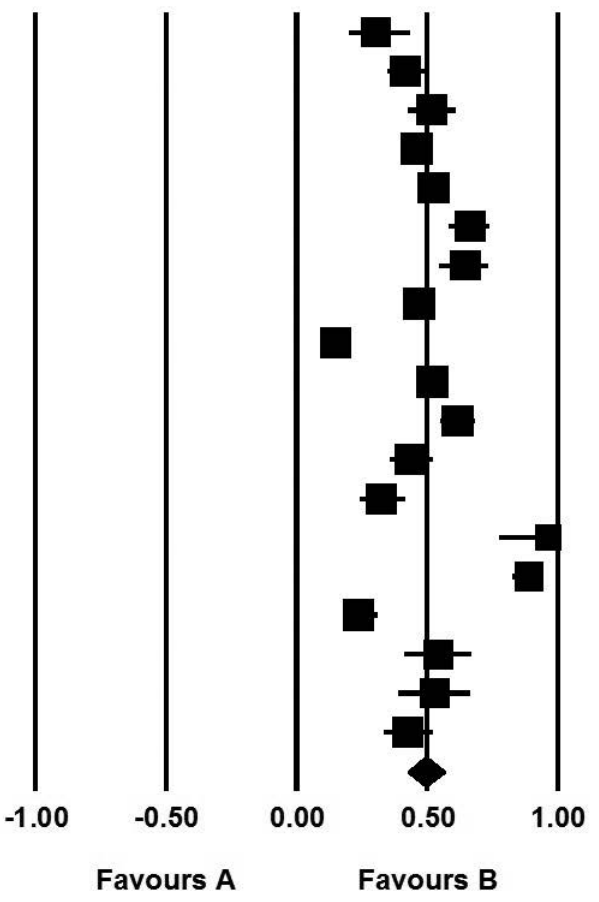

Meta Analysis

Figure 2. Forest plot of prevalence of HLGR among Enterococcus spp. in Iran.

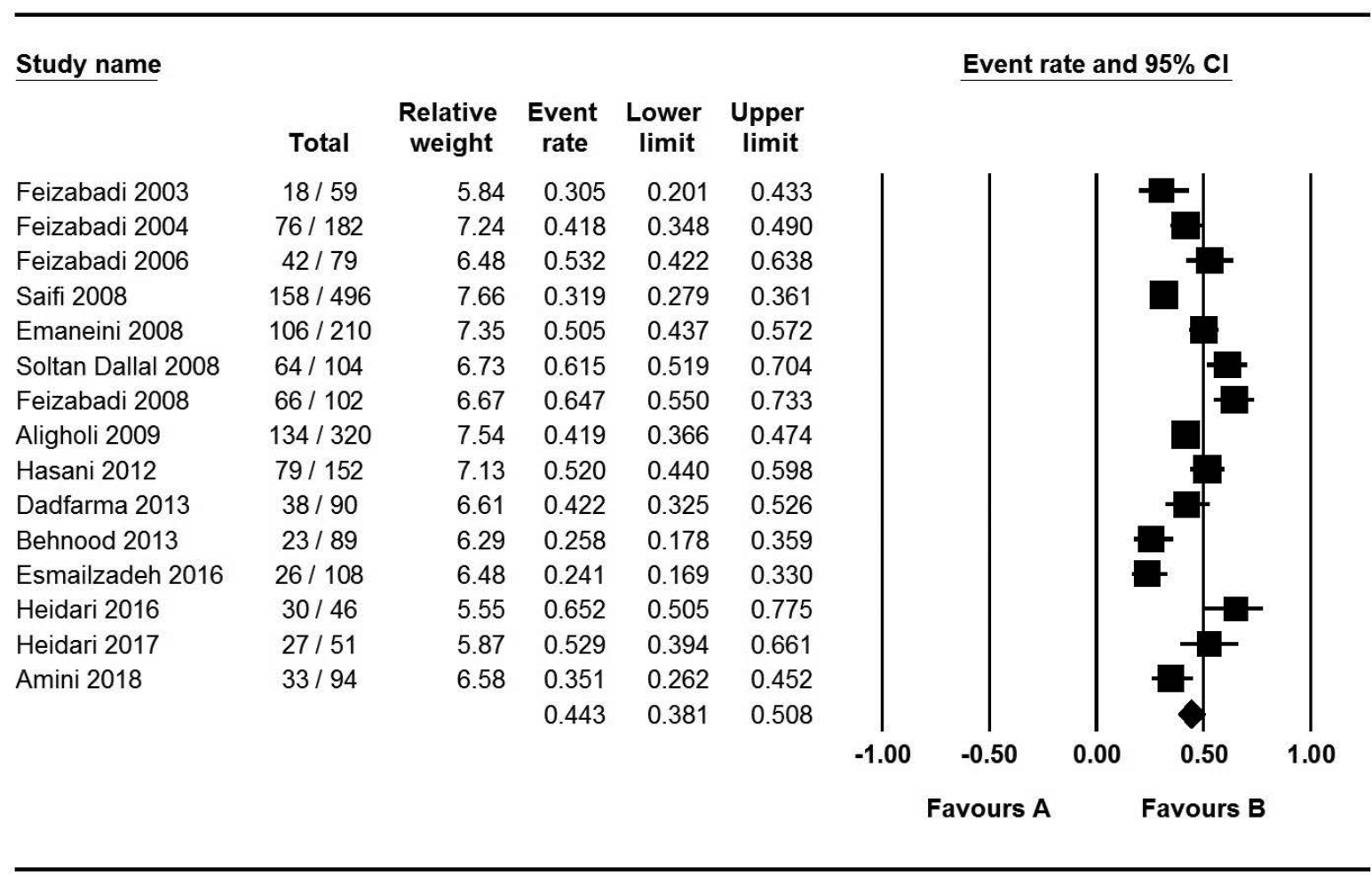

Meta Analysis

Figure 3. Forest plot of prevalence of HLGR among E. faecalis isolates in Iran. 


\section{Study name}

$\begin{array}{lcrccc} & \text { Total } & \begin{array}{r}\text { Relative } \\ \text { weight }\end{array} & \begin{array}{c}\text { Event } \\ \text { rate }\end{array} & \begin{array}{c}\text { Lower } \\ \text { limit }\end{array} & \begin{array}{c}\text { Upper } \\ \text { limit }\end{array} \\ \text { Feizabadi 2006 } & 17 / 35 & 10.41 & 0.486 & 0.327 & 0.647 \\ \text { Saifi 2008 } & 137 / 142 & 9.50 & 0.965 & 0.918 & 0.985 \\ \text { Emaneini 2008 } & 65 / 116 & 11.34 & 0.560 & 0.469 & 0.648 \\ \text { Soltan Dallal 2008 } & 34 / 43 & 10.14 & 0.791 & 0.644 & 0.887 \\ \text { Aligholi 2009 } & 93 / 157 & 11.45 & 0.592 & 0.514 & 0.666 \\ \text { Hasani 2012 } & 54 / 68 & 10.68 & 0.794 & 0.682 & 0.874 \\ \text { Dadfarma 2013 } & 21 / 47 & 10.73 & 0.447 & 0.312 & 0.589 \\ \text { Behnood 2013 } & 13 / 22 & 9.68 & 0.591 & 0.382 & 0.772 \\ \text { Esmailzadeh 2016 } & 17 / 72 & 10.83 & 0.236 & 0.152 & 0.347 \\ \text { Amini 2018 } & 13 / 14 & 5.22 & 0.929 & 0.630 & 0.990 \\ & & & 0.663 & 0.514 & 0.786\end{array}$

\section{Event rate and $95 \% \mathrm{Cl}$}

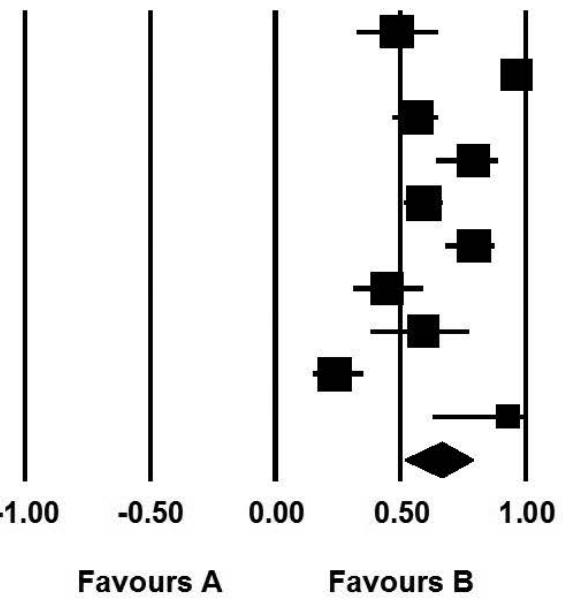

Meta Analvsis

Figure 4. Forest plot of prevalence of HLGR among E. faecium isolates in Iran.

enterococci that caused several infections in Iran. According to the meta-analysis results, the pooled prevalence of high-level gentamicin resistant Enterococcus isolates was 49.4\% (95\% CI: $42.2 \%-56.6 \%$ ). The prevalence of HLGR in Enterococcus in Iran is more than the one reported in a previous investigation in a neighbor country, Kuwait (14\%). ${ }^{27}$ However, high rates of HLGR in enterococcal bacteremia have been described in industrialized countries such as Korea $(63 \%)$ and Spain $(60.4 \%){ }^{28,29}$

Our results indicated that the pooled prevalence of high-level gentamicin resistant E. faecalis isolates was 44.3\% (95\% CI: 38.1\%-50.8\%). More rates have been reported from Saudi Arabia (75.3\%) and Taiwan (60\%). ${ }^{30,31}$ The prevalence of HLGR in E. faecalis in Iran was more than that in other countries such as Japan (34.2\%), Turkey (30\%), Kuwait (14.7\%), and USA (15\%)..$^{27,32-34}$ Nevertheless, notable HLGR prevalence of bacteremia causative E. faecalis strains has been reported from Spain (62.9\%), China (40.9\%), Denmark (38.2\%), New Zealand (38\%), and Japan (32\%). ${ }^{29,35-38}$

Based on the meta-analysis results, the pooled prevalence of HLGR in E. faecium isolates was $66.3 \%$ (95\% CI: $51.4 \%-78.6 \%)$ in Iran. It is more than the prevalence in two other Asian countries such as Kuwait (15.6\%) and Japan (9.2\%). ${ }^{27,32}$ Also, higher rates of HLGR in E. faecium (Up to $88 \%$ ) has been described in Turkey. ${ }^{33}$ However, high prevalence of high-level gentamicin resistant E. faecium isolated from blood stream was reported from developed countries such as Canada (71.6\%), Denmark (64.4\%), and Spain (53.8\%). ${ }^{29,35,39}$ It was lower for China (43.2\%), New Zealand (25\%), and Japan (24\%). ${ }^{36-38}$ The mentioned data, suggested that high-level gentamicin resistant strains pos- sess significant ability to cause invasive infections such as blood stream infection.

Prevalence of resistant enterococcal strains amongst patients may be due to several factors; recently, various studies described the effects of diet on gut microbiota composition. Special diet such as fiber (as a non-digestible carbohydrate) consumption change Enterococcus species population in gastrointestinal tract. ${ }^{40,41}$ Also, drug-resistant Enterococcus isolates of animal origin can easily contaminate the food chain and infect humans and affect the intestinal colonization. ${ }^{42,43}$ Hospitalization of colonized patients by such strains may lead to dissemination of drug-resistant strains in hospital environment and among patients. Therefore, diverse ranges of high-level gentamicin resistant enterococci isolated from hospitalized patients in various countries may be related to their diverse dietary habits.

Enterococci are able to survive under environmental stresses such as dryness and selective antimicrobial pressure. Therefore, hospital setting has an important role in the spread of resistant strains among patients and high-quality disinfection and cleaning of all surfaces and medical equipment are necessary. ${ }^{44-46}$ Inadequate efficacy of utilized disinfectant due to reduced biocide sensitivity in enterococci may be one of the major issues in the infection control implementation in hospitals.

In addition, unfavourable condition may induce viable-but-nonculturable (VBNC) strains. $^{44}$ This phenomenon can lead to transmission of resistant strains among patients, despite the effective appearance of the infection control policies.

Emergence of drug-resistant bacteria has accelerated by overuse and misuse of antibiotics. ${ }^{47,48}$ Ineffective ami- 
noglycosides prescription may contribute to selection of high-level gentamicin resistant strains. Colonization and dissemination of selected strains in hospital enhance the prevalence of HLGR among hospitalized patients.

HLGR in enterococci often occurs through acquisition of $a p h\left(2^{\prime \prime}\right)-I a-a a c\left(6^{\prime}\right)-I e$ gene. ${ }^{7}$ This bifunctional gene is most commonly located on a transposon. Therefore, horizontal gene exchange and acquired HLR traits will occur quickly among colonized Enterococcus spp. Other HLGR encoding genes are most frequently in E. faecium. ${ }^{7}$ It can explain the greater prevalence of HLGR among E. faecium strains.

Considering the mentioned features of enterococci, it seems that the most effective strategy among the many possible strategies for reducing the transmission of healthcare-associated infections, is hand hygiene compliance amongst healthcare workers. As mentioned in a previous systematic review in Iran, training of healthcare workers seems to be necessary for prevention and control of nosocomial infections. ${ }^{49}$

There are some limitations to the present review. First, only the published articles which were indexed in PubMed or Scopus were included in this meta-analysis. Secondly, few studies had been performed in different region of the country and most of the evaluated articles were related to Tehran (the capital of Iran).

\section{CONCLUSIONS}

The present systematic review indicates notable prevalence of high-level resistance to gentamicin amongst Enterococcus species in Iranian patients. According to the papers published from April 2000 to September 2018, diverse ranges were reported from Iran. This comprehensive analysis showed that, the prevalence of high-level gentamicin resistant Enterococcus spp. was $49.4 \%$. Also, the prevalence of HLGR in E. faecium strains was greater than that in E. faecalis. Therefore, improving the implementation of all aspects of the infection control programs according to the international standards is necessary.

\section{Conflict of Interest}

All authors declare no conflicts of interest.

\section{Funding}

No funding.

\section{REFERENCES}

1. Heidari H, Emaneini M, Dabiri H, et al. Virulence factors, antimicrobial resistance pattern and molecular analysis of Enterococcal strains isolated from burn patients. Microb Pathog 2016; 90:93-7.

2. Guzman Prieto AM, van Schaik W, Rogers MR, et al. Global emergence and dissemination of Enterococci as nosocomial pathogens: attack of the clones? Front Microbiol 2016; 7:788.

3. Miller WR, Munita JM, Arias CA. Mechanisms of antibiotic resistance in enterococci. Expert Rev Anti Infect Ther 2014; 12(10):1221-36.

4. Arias CA, Contreras GA, Murray BE. Management of multidrugresistant enterococcal infections. Clin Microbiol Infect 2010; 16(6):555-62.

5. O'Driscoll T, Crank CW. Vancomycin-resistant enterococcal infections: epidemiology, clinical manifestations, and optimal management. Infect Drug Resist 2015; 8:217-30.

6. Chow JW. Aminoglycoside resistance in enterococci. Clin Infect Dis 2000; 31(2):586-9.

7. Hollenbeck BL, Rice LB. Intrinsic and acquired resistance mechanisms in enterococcus. Virulence 2012; 3(5):421-33.

8. Dadfarma N, Imani Fooladi AA, Oskoui M, et al. High level of gentamicin resistance (HLGR) among enterococcus strains isolated from clinical specimens. J Infect Public Health 2013; 6(3):202-8.

9. Heidari H, Hasanpour S, Ebrahim-Saraie HS, et al. High incidence of virulence factors among clinical Enterococcus faecalis isolates in Southwestern Iran. Infect Chemother 2017; 49(1):51-6.

10. Behnood A, Farajnia S, Moaddab SR, et al. Prevalence of aac(6')-Ieaph(2")-Ia resistance gene and its linkage to Tn5281 in Enterococcus faecalis and Enterococcus faecium isolates from Tabriz hospitals. Iran J Microbiol 2013; 5(3):203-8.

11. Amini FM, Krimpour HAP, Ghaderi MM, et al. Prevalence of aminoglycoside resistance genes in Enterococcus strains in Kermanshah, Iran. Iran J Med Sci 2018; 43(5):487-93.

12. Wayne P. Clinical and Laboratory Standard Institute (CLSI). Performance standards for antimicrobial susceptibility testing. 27th informational supplement. 2017 M100-S126.

13. Feizabadi MM, Aliahmadi A, Mobasheri F, et al. Phenotypic characteristics and population genetics of Enterococcus faecalis cultured from patients in Tehran during 2000-2001. Can J Microbiol 2003; 49(10):645-9.

14. Feizabadi MM, Asadi S, Zohari M, et al. Genetic characterization of high-level gentamicin-resistant strains of Enterococcus faecalis in Iran. Can J Microbiol 2004; 50(10):869-72.

15. Feizabadi MM, Maleknejad P, Asgharzadeh A, et al. Prevalence of aminoglycoside-modifying enzymes genes among isolates of Enterococcus faecalis and Enterococcus faecium in Iran. Microb Drug Resist 2006; 12(4):265-8.

16. Saifi M, Pourshafie MR, Eshraghian MR, et al. Anti-microbial resistance of Enterococci isolated from urinary tract infections in Iran. Iran Biomed J 2008; 12(3):185-90.

17. Emaneini M, Aligholi M, Aminshahi M. Characterization of glycopeptides, aminoglycosides and macrolide resistance among Enterococcus faecalis and Enterococcus faecium isolates from hospitals in Tehran. Pol J Microbiol 2008; 57(2):173-8.

18. Soltan-Dallal M, Pourshafie MR, Eshraghian MR. High-level gentamicin-resistant enterococcal isolates from urinary tract infection in Iran. Infect Dis Clin Pract 2008; 16(1):41-5.

19. Feizabadi M, Sayady S, Asadi S. Transposon Tn5281 is the main distributor of the aminoglycoside modifying enzyme gene among isolates of Enterococcus faecalis in Tehran hospitals. Can J Microbiol 2008; 54:887-90.

20. Aligholi M, Jabalameli F, Shahsavan S, et al. Antibiotic susceptibility 
pattern of gram-positive Cocci cultured from patients in three university hospitals in Tehran, Iran during 2001-2005. Acta Med Iran 2009; 47(4):329-34.

21. Saifi M, Pourshafie MR, Dallal MM, et al. Clonal groups of high-level gentamicin-resistant Enterococcus faecium isolated from municipal wastewater and clinical samples in Tehran, Iran. Lett Appl Microbiol 2009; 49(2):160-5.

22. Jabalameli F, Shahsavan S, Sedaghat H, et al. Evaluation of antimicrobial susceptibility patterns of Enterococci isolated from patients in Tehran University of Medical Sciences Teaching Hospitals. Acta Med Iran 2009; 47(4):325-8.

23. Hasani A, Sharifi Y, Ghotaslou R, et al. Molecular screening of virulence genes in high-level gentamicin-resistant Enterococcus faecalis and Enterococcus faecium isolated from clinical specimens in Northwest Iran. Indian J Med Microbiol 2012; 30(2):175-81.

24. Emaneini M, Khoramian B, Jabalameli F, et al. Prevalence of high-level gentamicin-resistant Enterococcus faecalis and Enterococcus faecium in an Iranian hospital. J Prev Med Hyg 2016; 57(4):E197-e200.

25. Khani M, Fatollahzade $M$, Pajavand $H$, et al. Increasing prevalence of aminoglycoside-resistant Enterococcus faecalis isolates due to the $\operatorname{aac}\left(6^{\prime}\right)-\operatorname{aph}\left(2^{\prime \prime}\right)$ gene: a therapeutic problem in Kermanshah, Iran. Jundishapur J Microbiol 2016; 9(3):e28923.

26. Esmailzadeh M, Moniri R, Gilasi HR, et al. Distribution of gentamicin resistant genes of nosocomial enterococcus spp from intensive care unit of Shahid Beheshty Hospital in Kashan, Iran. J Pure Appl Microbiol 2016; 10(3):1919-26.

27. Udo EE, Al-Sweih N, Phillips OA, et al. Species prevalence and antibacterial resistance of enterococci isolated in Kuwait hospitals. J Med Microbiol 2003; 52(Pt 2):163-8.

28. Jang HC, Lee S, Song KH, et al. Clinical features, risk factors and outcomes of bacteremia due to enterococci with high-level gentamicin resistance: comparison with bacteremia due to enterococci without high-level gentamicin resistance. J Korean Med Sci 2010; 25(1):3-8.

29. Garcia-Vazquez E, Albendin H, Hernandez-Torres A, et al. [Study of a cohort of patients with Enterococcus spp. Bacteraemia. Risk factors associated to high-level resistance to aminoglycosides]. Rev Esp Quimioter 2013; 26(3):203-13 [Article in Spanish].

30. El-Kersh TA, Marie MA, Al-Sheikh YA, et al. Prevalence and risk factors of early fecal carriage of Enterococcus faecalis and Staphylococcus spp and their antimicrobial resistant patterns among healthy neonates born in a hospital setting in central Saudi Arabia. Saudi Med J 2016; 37(3):280-7.

31. McDonald LC, Lauderdale TL, Shiau YR, et al. The status of antimicrobial resistance in Taiwan among Gram-positive pathogens: the Taiwan Surveillance of Antimicrobial Resistance (TSAR) programme, 2000. Int J Antimicrob Agents 2004; 23(4):362-70.

32. Osuka H, Nakajima J, Oishi T, et al. High-level aminoglycoside resistance in Enterococcus faecalis and Enterococcus faecium causing invasive infection: Twelve-year surveillance in the Minami Ibaraki Area. J Infect Chemother 2016; 22(1):61-3.

33. Erdem $\mathrm{H}$, Oncul O. A review of the current place of glycopeptides in Turkish medical practice. Curr Ther Res Clin Exp 2007; 68(1):49-66.
34. Chowdhury SA, Nallapareddy SR, Arias CA, et al. The majority of a collection of U.S. endocarditis Enterococcus faecalis isolates obtained from 1974 to 2004 lack capsular genes and belong to diverse, nonhospital-associated lineages. J Clin Microbiol 2014; 52(2):549-56.

35. Pinholt M, Ostergaard C, Arpi M, et al. Incidence, clinical characteristics and 30-day mortality of enterococcal bacteraemia in Denmark 2006-2009: a population-based cohort study. Clin Microbiol Infect 2014; 20(2):145-51.

36. Wang X, Zhao C, Li H, et al. [Microbiological profiles of pathogens causing nosocomial bacteremia in 2011, 2013 and 2016]. Sheng $\mathrm{Wu}$ Gong Cheng Xue Bao 2018; 34(8):1205-17 [Article in Chinese].

37. Araoka H, Kimura M, Yoneyama A. A surveillance of high-level gentamicin-resistant enterococcal bacteremia. J Infect Chemother 2011; 17(3):433-4.

38. McBride SJ, Upton A, Roberts SA. Clinical characteristics and outcomes of patients with vancomycin-susceptible Enterococcus faecalis and Enterococcus faecium bacteraemia - a five-year retrospective review. Eur J Clin Microbiol Infect Dis 2010; 29(1):107-14.

39. McCracken M, Wong A, Mitchell R, et al. Molecular epidemiology of vancomycin-resistant enterococcal bacteraemia: results from the Canadian Nosocomial Infection Surveillance Program, 1999-2009. J Antimicrob Chemother 2013; 68(7):1505-9.

40. Tomova A, Bukovsky I, Rembert E, et al. The effects of vegetarian and vegan diets on gut microbiota. Front Nutr 2019; 6:47.

41. Rinninella E, Cintoni M, Raoul P, et al. Food components and dietary habits: keys for a healthy gut microbiota composition. Nutrients 2019; 11(10):2393.

42. Torres C, Alonso CA, Ruiz-Ripa L, et al. Antimicrobial resistance in Enterococcus spp. of animal origin. Microbiol Spectrum 2018;6(4):ARBA0032-2018. doi:10.1128/microbiolspec.ARBA-0032-2018

43. Manson AL, Van Tyne D, Straub TJ, et al. Chicken meat-associated Enterococci: influence of agricultural antibiotic use and connection to the clinic. Appl Environ Microbiol 2019;85(22).

44. Byappanahalli MN, Nevers MB, Korajkic A, et al. Enterococci in the environment. Microbiol Mol Biol Rev 2012; 76(4):685-706.

45. Agudelo Higuita NI, Huycke MM. Enterococcal disease, epidemiology, and implications for treatment. In: Gilmore MS, Clewell DB, Ike Y, Shankar N, editors. Enterococci: From Commensals to Leading Causes of Drug Resistant Infection. Boston: Massachusetts Eye and Ear Infirmary; 2014.

46. Mehta Y, Gupta A, Todi S, et al. Guidelines for prevention of hospital acquired infections. Indian J Crit Care Med 2014; 18(3):149-63.

47. Alp E, Damani N. Healthcare-associated infections in intensive care units: epidemiology and infection control in low-to-middle income countries. J Infect Dev Ctries 2015; 9(10):1040-45.

48. Llor C, Bjerrum L. Antimicrobial resistance: risk associated with antibiotic overuse and initiatives to reduce the problem. Ther Adv Drug Saf 2014; 5(6):229-41.

49. Emaneini M, Beigverdi R, van Leeuwen WB, et al. Prevalence of methicillin-resistant Staphylococcus aureus isolated from burn patients in Iran: A systematic review and meta-analysis. J Glob Antimicrob Resist 2018; 12:202-6. 


\title{
Устойчивость к гентамицину высокого уровня среди клинических изолятов энтерококков в Иране: систематический обзор и метаанализ
}

\author{
Милад Шахини Шамс Абади ${ }^{1}$ Асиех Таджиㄹ, Фатемех Салехи ${ }^{3}$, Хосеин Каземиан $^{4}$, \\ Хамид Хеидари ${ }^{5}$ \\ ${ }^{1}$ Кафедра микробиологии и иммунологии, Центр клеточных и молекулярных исследваний, Институт фундаментальных медицинских наук, \\ Университет медицинских наук Шахрекорд, Шахрекорд, Иран. \\ ${ }^{2}$ Кафедра бактериологии и вирусологии, Медицинский факультет, Ширазский университет медицинских наук, Шираз, Иран \\ ${ }^{3}$ Исследовательский центр медицинского моделирования, Университет медицинских наук Шахрекорд, Шахрекорд, Иран. \\ ${ }^{4}$ Кафедра микробиологии, Медицинский факультет, Иламский университет медицинских наук, Илам, Иран \\ ${ }^{5}$ Кафедра микробиологии, Медицинский факультет, Университет медицинских наук, Шахида Садуги, Йезд, Иран
}

Адрес для корреспонденции: Хамид Хеидари, Кафедра микробиологии, Медицинский факультет, Университет медицинских наук Шахида Садуги, Йезд, Иран; E-mail: heidarii.hamid@gmail.com; Tel.: +98-9386312941

Дата получение: 22 апреля 2020 Дата приемки: 1 июня $2020 \bullet$ Дата публикации: 28 февраля 2021

Образец цитирования: Abadi MSS, Taji A, Salehi F, Kazemian H, Heidari H. High-level gentamicin resistance among clinical isolates of enterococci in Iran: A systematic review and meta-analysis. Folia Med (Plovdiv) 2021;63(1):15-23. doi: 10.3897/folmed.63. e53506.

\section{Резюме}

Enterococci считаются одной из наиболее частых причин внутрибольничных инфекций. Высокая устойчивость к аминогликозидам приводит к недостаточности синергетической комбинированной терапии.

Целью этого исследования было оценить частоту высокой устойчивости к гентамицину (HLGR) среди клинических изолятов энтерококков в Иране.

Был проведён систематический обзор литературы в электронных базах данных Web of Science, PubMed, Scopus и Google Scholar на предмет поиска статей, опубликованных с апреля 2000 г. по сентябрь 2018 г. Поиск в доступной литературе выявил 918 исследований. Подходящие исследования были отобраны в соответствии с заранее определенными критериями включения и исключения. Статистическая неоднородность измерялась Q-статистикой и индексом I². Для оценки возможной субъективности публикаций использовались тест ранговой корреляции Бегга и регрессионный тест Эгера.

В этот обзор было включено девятнадцать исследований. По результатам метаанализа частота HLGR к Enterococcus spp. составила 49.4\% (95\% CI: 42.2\% -56.6\%). Результаты показали 44.3\% (95\% CI: 38.1\% -50.8\%) и 66.3\% (95\% CI: 51.4\% -78.6\%) для E. faecalis и E. faecium, соответственно.

Поскольку в ходе этого анализа была обнаружена высокая частота HLGR в отношении enterococсі, мы пришли к выводу, что необходимо улучшить все аспекты процедур инфекционного контроля, чтобы уменьшить распространение таких инфекций.

\section{Ключевые слова}

Enterococcus, Иран, высокая устойчивость к гентамицину (HLGR), метаанализ, систематический обзор 